\title{
TRENDS OF WOMEN'S CANDIDACY IN NATIONAL ELECTIONS OF NEPAL
}

\author{
Amrit Kumar Shrestha \\ Lecturer (Political Science) \\ Mahendra Multiple Campus, Dharan \\ amrit365@gmail.com
}

\begin{abstract}
The study area of this article is women's candidacy in national elections of Nepal. It focuses on five national elections held from 1991 to 2013. It is based on secondary source of data. The Election Commission of Nepal publishes a report after every election. Data are extracted from the reports published by the Election Commission and analyzed with the help of the software SPSS. This article analyzes only facts regarding the first-past-the-post (FPTP) electoral system. Such a study is important in order to lead to new affirmative action policies that will enhance gender mainstreaming and effective participation in all leadership and development processes. The findings will also be resourceful to scholars who are working in this field. The findings from this investigation provide evidence that the number of women candidates in national elections seems almost invisible in an overwhelming crowd of men candidates. The number of elected women candidates is very few. Similarly, distribution of women candidates is unequal in geographical regions. Where the human development rate is high the number of women candidates is greater. The roles of political parties of Nepal are not profoundly positive to increase women's candidacy. Likewise, electoral systems are responsible to influence women's chances of being elected. FPTP electoral system is not more favorable for women candidates. This article recommends that if a constituency would reserve only for women among three through FPTP then the chances of 33 percent to win the elections by women would be secured.
\end{abstract}

Keywords: FPTP, candidate, House of Representatives (HoR), gender mainstreaming, electoral system, women candidacy, Constituent Assembly (CA). 


\section{Introduction}

Among the various terms and conditions of the modern representative democracy, the periodic election is a most important element. According to IPU (2018, p. 1),"Elections may not be the full test of democracy, but they do present an opportunity for democracy to be tested." Elections link between people and political parties, provides a channel of communication between voters and their representatives, and the government gets legitimacy from society through the elections. For citizens, the election is an exercise of their voting rights and many more, i.e. political participation, dialogue with political actors, negotiation with the political elite, choice of an individual candidate and/or choice of party's policy etc. (Hachhethu, 2005, p. 156).

Nepal has very short history of elections. Altogether ten national elections were held in Nepal to till date. The first ever elections held in Nepal was Kathmandu municipal elections in 1947. The election was held in the month of June (1947) (Gupta, 1964, p. 31). During the first phase of democracy in the country from 1951 to 1960, elections to the Local Village Administration Body or the Gaun Panchayat and Municipalities were held. Sadhana Pradhan, who was elected as a member of the Kathmandu Municipality in 1953, is the first elected woman in Nepal (Malla, 2011, p. 48). Whereas, Nepal's first parliamentary election took place in 1959 to elect the 109 members of - the House of Representatives - the lower house of parliament. It was Nepal's first experiment with national elections. Dwarika Devi Thakurani was the only a candidate from Dadeldhura, elected from women candidates (Lama, Khakurel, Agrawal, \& Shrestha, 2011, p. 38).

During the Panchayat period, three general elections were held in the country. Because of the public demand for the abolition of the party-less system in 1979, a referendum was called by the King to ascertain popular opinion on the issue. Following the royal proclamation of 24 May 1979, government launch a national referendum on 2 May 1980 to choose between the then party-less Panchayat System "with suitable reforms" or return to the multiparty system. Nepali voters chose the Panchayat system by a narrow margin of $54.7 \%$ (Gurung, 1982, P. 304). During the campaign, the Panchayat proponents promised a directly elected Rashtriya Panchayat (IIDS, 1993, p. 7). On 15 December 1980, the king promulgated 
the third amendment on Constitution of Nepal. The main provision of the amendment was direct elections to the Rashtriya Panchayat; it would be held every five years for 112 seats with 28 additional seats filled by the King's personal nomination (Election Commission, 2015).

In accordance with the provision of the third amendment of the constitution, direct elections to the Rashtriya Panchayat were were held in 1981 and 1986 (Gaige \& Scholz, 1991, p. 1041). In the first election, only two women, Nanimaiya Dahal from Kathmandu and Bhadra Ghale from Sindhuli won (HMG, 2038). Three women were elected in the second election. They were Sharda Mall from Dhanusa, Laxmi Sinha from Sarlahi, and Chanda Shah from Bara (HMG, 2043).

After the political change in 1990, three national elections were held to elect 205 members of House of Representatives (HoR) and two elections were held to choose representatives of local bodies. Similarly, two national elections were held after the uprising of 2006 to establish the Constituent Assembly (CA). Likewise, in accordance with the constitution of Nepal 2015, elections of federal, provincial, and local level were held in 2017.

According to IPU (2018, p. 3), over the past 23 years (from 1995 to 2018), women representation have been increasing in a positive way. The most increased percent in the period was the American region and the least was Asia. The world average was increased by 12.1 percent; as a result, recent representation of women in politics is 23.4 percent in worldwide. The Arab States are considered to be more conservative in the matter of women's representation, but data presented the progress of 13.2 percent within the period. However, the number of women in parliament is not enough in comparison to their men counterparts.

The sexual difference theories understand that there are male-created and male-centered philosophies, literature, and psychoanalysis in a society that considers woman as "the Other" (Lengermann \& Niebrugee, 2010, p. 463). Unlike this, women are treated as "the Other" in politics, too. Thus, the male-dominant culture is the main reason why women stay away from politics (Leyenaar, 2008, p. 5).Women were noticed rarely in few constituencies. It happened because the political model is set up as a masculine model. As Shvedova (2005, p. 35) finds, 
"Political life is organized according to male norms and values and in some cases even male lifestyles."

Most of the US men and women agree that the electoral environment is more difficult for women than men. In fact, many women state outright that they are not qualified to run for office simply because they are the wrong sex (Lawless \& Fox, 2010, p. 124). As Nancy Pelosi (the 52nd Speaker of the United States House of Representatives, from 2007 to 2011, the only woman Speaker until to date), says, "The word 'campaign' is a war term. So when you go into a campaign you just prepare to go to war" (Herrnson \& Stokes, 2003, p. 244). Thus, women have to work harder than men to achieve similar electoral results (Fulton, 2012, p. 304). These factors hinder women to enter into electoral politics, therefore, the number of women candidates seem few in worldwide as well as Nepal, too.

This article analyzes the data from three HoR elections held in 1991, 1994 and 1999. Similarly, it concentrates the facts of two CA elections held in 2008 and 2013. It focuses on women candidacy in those national elections of Nepal.

\section{Statement of the Problem}

Women constitute slightly more than half of the total population of the country but only a few numbers of women are seen in the political domain. Women's position has been subordinated to men authority within the household, family, clan, community, and state. In their public and private lives, women have to struggle hard to articulate their desires and find their own voices. Women have spent their huge energy and time only for obtaining the right to vote and be elected to political offices in many countries. There are many obstacles and hindrances for women to be candidates for elections. They have to face more challenges during the election campaigns as women candidates. Gender issues in electoral politics have not received due attention. While a few researchers have, in the recent past, began to document on women's participation in various part of public life. Such documentation, however, has not focused on the status of women's participation in electoral politics. This article, therefore, intends to search the facts of women's participation in electoral politics in Nepal. 
The article seeks to answer the following questions:

1. What were the trends of women candidacy in the past national elections of Nepal?

2. What were the statuses of women candidates in various geographic and nongeographic levels?

\section{Objectives}

The general objective of the article is to analyses of facts of women's participation in electoral politics in general elections of Nepal. Specifically, the study aims:

1. To identify the status of women candidates in national elections of Nepal in general from 1991 to 2013.

2. To trace the trends of women candidates in various levels.

\section{Materials and methods}

This article is mainly depended on secondary data. Election Commission of Nepal publishes a report after every election. In these reports, name, age, gender, concerning the political party, obtained votes, and percent of votes obtained by the candidates have been mentioned. Because of publication of Election Commission, election management constitutional body of Nepal, data of report are authentic and reliable for analysis. This article has mainly based on these data. Data drawn from the report have inserted in a StatisticalPackage for the Social Sciences (SPSS), a software program, and analyzed them. Descriptive and analytical research designs have used for the analysis.

\section{Women candidates in national level}

As table-1 shows, the number of women candidates for national elections of Nepal was very low in comparison to men candidates. The numbers of women candidates were increasing gradually; however, in term of percentage, women's candidacy has not been increased significantly. There were 80 women candidates in HoR election in 1991; in contrast, there were 1265 men candidates. The ratio between women and men candidates of the election was $1: 16$. It was a huge gap in gender wise candidacy. 
Table 1: Gender wise candidates of general elections of Nepal

\begin{tabular}{llllllllllll}
\hline \multirow{2}{*}{ Gender } & \multicolumn{3}{l}{ Election 1991 Election 1994 } & \multicolumn{1}{l}{ Election 1999 } & \multicolumn{2}{l}{ Election 2008 } & \multicolumn{2}{l}{ Election 2013} \\
\cline { 2 - 11 } & $\mathrm{N}$ & $\%$ & $\mathrm{~N}$ & $\%$ & $\mathrm{~N}$ & $\%$ & $\mathrm{~N}$ & $\%$ & $\mathrm{~N}$ & $\%$ \\
\hline Male & 1265 & 94.05 & 1356 & 94.04 & 2095 & 93.61 & 3577 & 90.65 & 5458 & 89.09 \\
Female & 80 & 5.95 & 86 & 5.96 & 143 & 6.39 & 369 & 9.35 & 667 & 10.89 \\
Third Sex & 0 & 0.00 & 0 & 0.00 & 0 & 0.00 & 0 & 0.00 & 1 & 0.02 \\
\hline Total & 1345 & 100.00 & 1442 & 100.00 & 2238 & 100.00 & 3946 & 100.00 & 6126 & 100.00 \\
\hline
\end{tabular}

Source: Election Commission 1992, 2051 B.S., 2056 B.S., 2065 B.S. \& 2070 B.S.

In CA election 2013, 667 women fielded their candidacy. It shows the increasing level of women's involvement in electoral politics. But, the percentage of women could not exceed 11 of total candidates. In the election, the ratio between women and men candidates reduced in point of 1:10; however,still, a visible gap exists.

\section{Elected women candidates}

As shown in table 2, very few women candidates could win in the national elections. Only 7 women elected in both HoR elections 1991 and 1994 out of 205 seats. The success percent of women candidates was 8.75 percent in 1991 and 8.14 percent in 1994. Similarly, 12 women candidates won the HoR election in 1999; the success of women candidates was 8.39 percent in the election.

Table 2: Gender Wise Elected Candidates of national elections of Nepal in FPTP electoral system

\begin{tabular}{|c|c|c|c|c|c|c|c|c|c|c|}
\hline \multirow{2}{*}{ Gender } & \multicolumn{2}{|c|}{ Election 1991} & \multicolumn{2}{|c|}{ Election 1994} & \multicolumn{2}{|c|}{ Election 1999} & \multicolumn{2}{|c|}{ Election 2008} & \multicolumn{2}{|c|}{ Election 2013} \\
\hline & $\mathrm{N}$ & $\%$ & $\mathrm{~N}$ & $\%$ & $\mathrm{~N}$ & $\%$ & $\mathrm{~N}$ & $\%$ & $\mathrm{~N}$ & $\%$ \\
\hline Male & 198 & 96.59 & 198 & 96.59 & 193 & 94.15 & 210 & 87.50 & 230 & 95.83 \\
\hline Female & 7 & 3.41 & 7 & 3.41 & 12 & 5.85 & 30 & 12.50 & 10 & 4.17 \\
\hline Total & 205 & 100.00 & 205 & 100.00 & 205 & 100.00 & 240 & 100.00 & 240 & 100.00 \\
\hline
\end{tabular}

Source: Election Commission, 1992, 2051 B.S., 2056 B.S., 2065 B.S. \& 2070 B.S. 
Likewise, 30 women candidate won the CA election in 2008 out of 240 seats. The success of women candidates was 8.13 percent. Only 10 women candidates won the CA election 2013 and the percent of the success of women candidates was 1.50 .

\section{Distribution of women candidates}

Figure-1 shows that the distribution of women candidates was unequal in the regional level. In HoR election 1991, the ratio between women and men candidates was 1:83, the highest gap recorded in the far-western region. The least gap was in the central region. Then, Western, Eastern, and Mid-western contained lower to the higher ratio between women and men candidates respectively.

Figure 1: Region-wise men candidates per one woman candidate

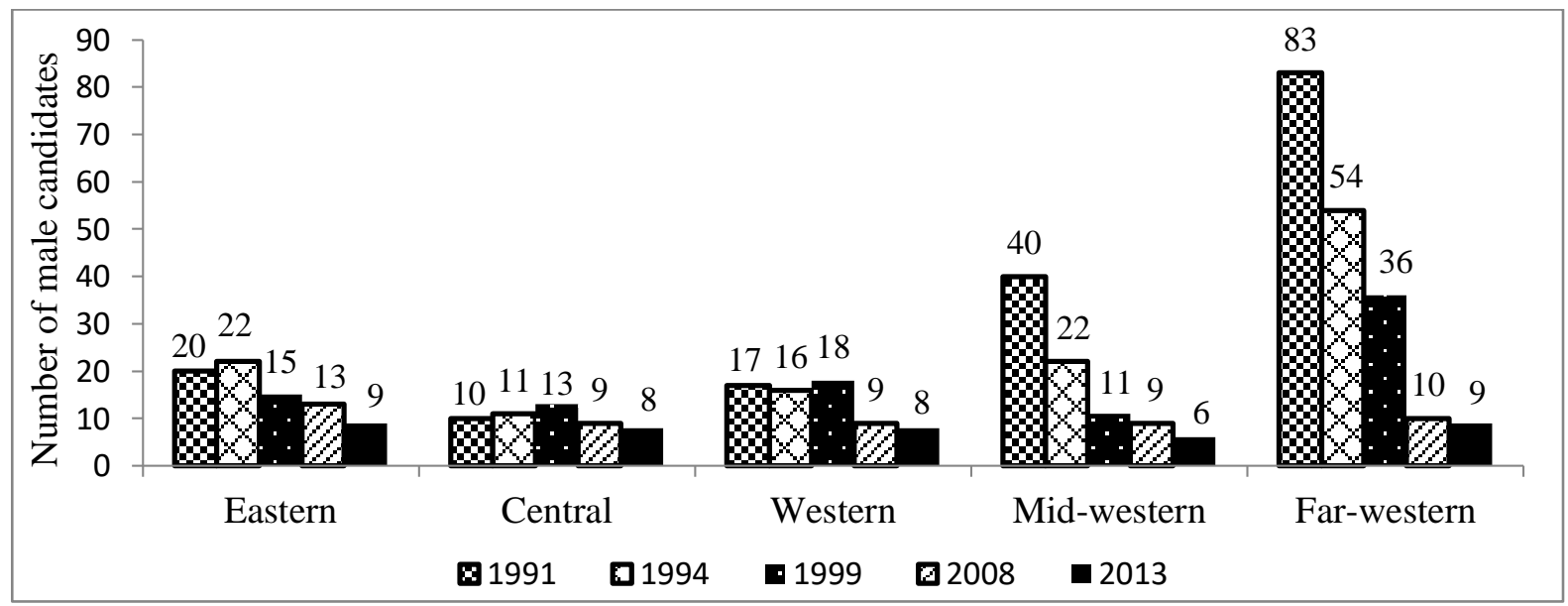

Source: Election Commission (1992, 2051 B.S., 2056 B.S., 2065 B.S. \& 2070 B.S.)

According to United Nations Development Programme (UNDP) (2004, p. 141), the Midwestern and Far-western region had the lowest Human Development Index (HDI), 0.402 and 0.404 respectively; whereas eastern, central, and western region had $0.493,0.490$, and 0.491 respectively. The distribution of women candidates is as like the situation of the human development of concern regions. It proved that where the human development is high there the candidacy of women is high. Similarly, the Mid-western and Far-western region had a higher rate of Human Poverty Index (HPI) in comparison to the rest of the regions (UNDP, 2004, p. 144). Likewise, the Gender Empowerment Measure (GEM) was lower in mid and far 
western regions. They had 0.363 and 0.368 GEM respectively, on the other hand, the Eastern, Central, and Western regions had 0.382, 0.407, 0.395 GEM respectively (UNDP, 2004, p. 150). It proved that HPI and GEM also responsible for women candidacy.

In the ecological region, the Hills had constantly lower gap between women and men candidates in comparison of another two ecological regions (figure-2). The Mountain region had a huge gap. For example, in HoR election 1991, there were 91 men candidates, in against of this; there was only one woman candidate in the region.

Figure 2: Ecological region wise men candidates per one woman candidate

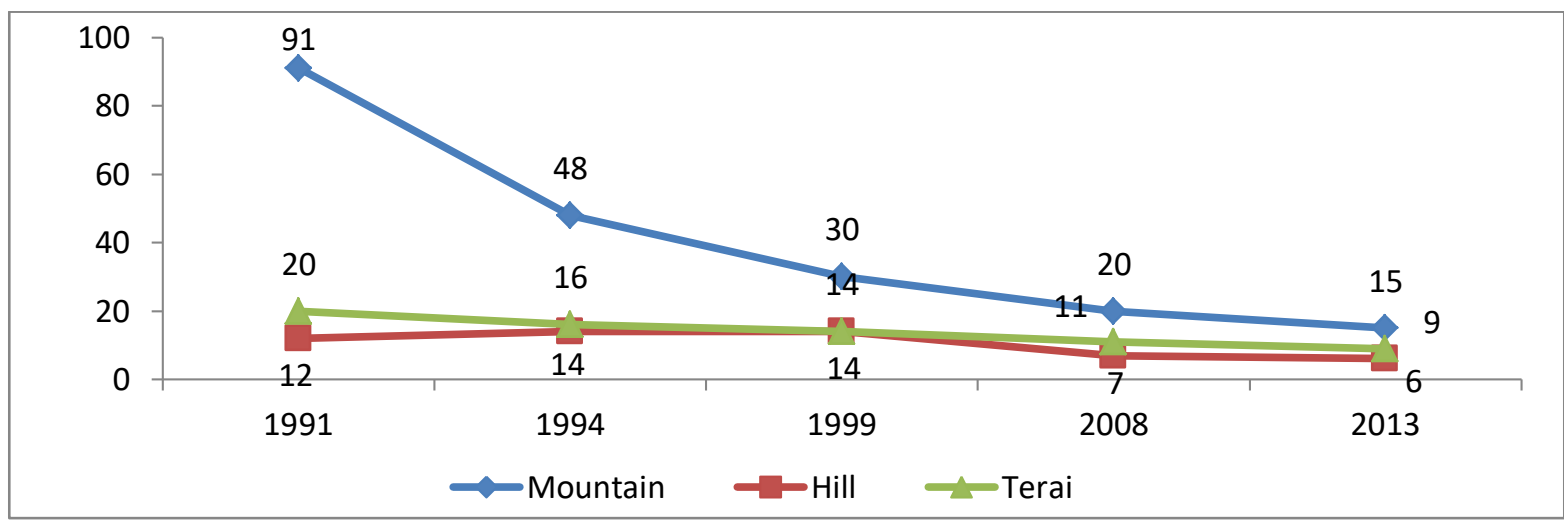

Source: Election Commission (1992, 2051 B.S., 2056 B.S., 2065 B.S. \& 2070 B.S.)

Unlike regional level, HDI, HPI, and GEM are responsible factors for unequal distribution of women candidates. Mountain region had 0.386 HDI, whereas Hills had 0.512 and Tarai had 0.478 HDI (UNDP, 2004, p. 141). Mountain region had lower human development situation in the comparison to the other two regions. Similarly, Mountain had got behind the Hills and Tarai in GEM, too (UNDP, 2004, p. 150). But, HPI was higher in Mountain than Hills and Tarai. So, where the life expectancy, adult literacy, and per capita is higher the number of women candidates is higher and vice-versa.

According to figure-3, among 75 districts of Nepal, 44 had not single woman candidates in HoR election 1991. The number of zero woman candidate was in falling level constantly, however, there was still 30 such district where there was not a woman candidate 
in CA election 2013. It means voters of 40 percent districts of Nepal could not see a single woman candidate in the national election even in 2013.

Figure 3: Percent of women candidates and number of district

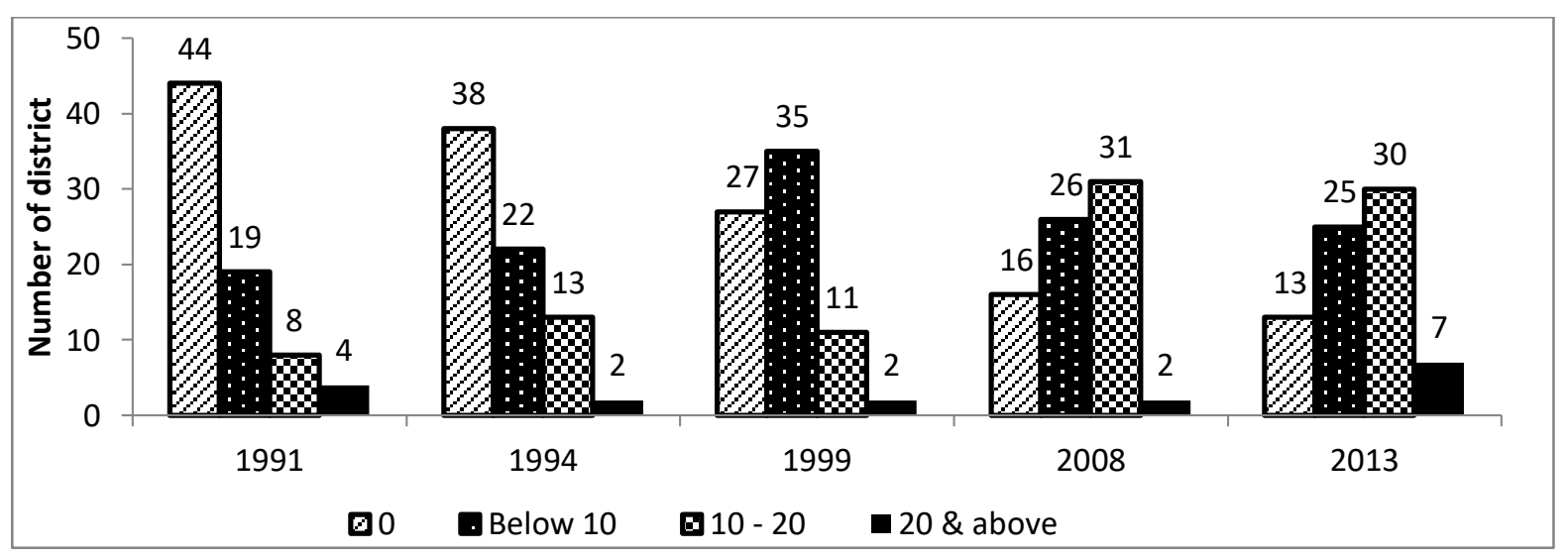

Source: Election Commission (1992, 2051 B.S., 2056 B.S., 2065 B.S. \& 2070 B.S.)

As figure- 4 shows, a large number of constituencies were without awoman candidate. Out of 205 constituencies, 153 (75\%) were occupied only by men candidates. The number of no woman candidate constituency is gradually decreasing; however, 43 constituencies (out of 240) were still without women candidates in CA election 2013. Similarly, the number of constituency having more than 30 percent women candidates seems very scanty.

Figure 4: Percent of women candidates and number of constituency

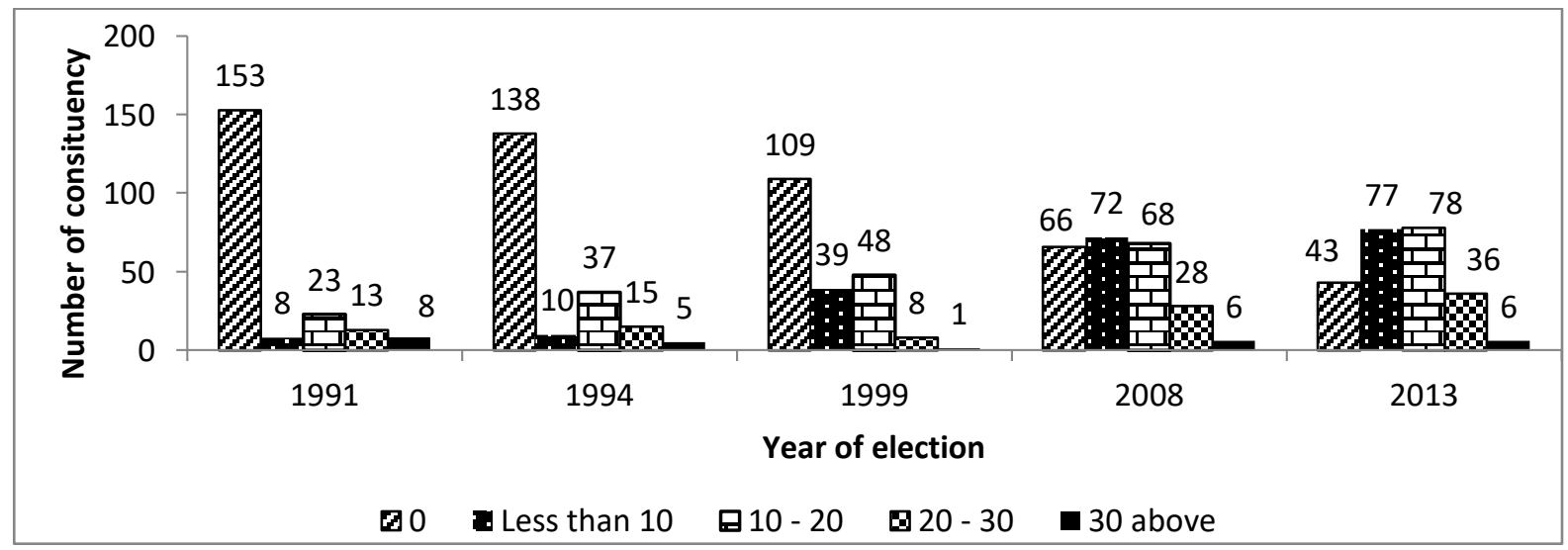

Source: Election Commission (1992, 2051 B.S., 2056 B.S., 2065 B.S. \& 2070 B.S.)

Researcher (Vol. 3, No. 3, January 2018) 
The trend of women candidates seems that they were mainly centered at the facilitated area. For example, there were 28 (out of 80 or $35.00 \%$ ) women candidates in HoR elections 1991, 21 (out of 86 or 24.42\%) in HoR elections 1994, and 32 (out of 143 or 22.38\%) women candidates in HoR elections 1999 were only in Kathmandu valley. Likewise, in the CA elections 2008, 74 (out of 369 or 20.05\%) women candidates and in the CA elections 2013, 101 (out of 667 or $15.14 \%$ ) women candidates were in only Kathmandu valley. Similarly, the Tarai region comprised most women candidates and Mountain region had the least women candidates.

\section{Political party and women candidacy}

In HoR elections of 1991, 1994, and 1999, the major political parties have intended only to meet the provision of the constitution of the kingdom of Nepal (1990) of five percent representation of women candidates in a ritual manner. However, political parties fielded more than 10 percent women as their candidates in CA elections 2008 and 2013.

It is also found that political parties nominated women candidates at those constituencies where chances to win the elections were very low. It is the same in other countries of the world. In Australia, for example, parties might reserve the seats that easily can be won for men, leaving women with a token of nominations where their party has little or no chance of electoral victory (Studlar \& McAllister, 1991, p. 474). Research reveals the same situation in Sierra Leone, an African Country. All of the APC (All People's Congress, the ruling party) candidates in the 2008 local elections standing in Bo District - a notoriously SLPP (Sierra Leone People's Party, the opposition party) area - were women, and they all lost the elections (Kellow, 2010, p. 21). The story of Nepal is also the same. Many Tarai centered parties allocated most of their women candidates in Kathmandu valley and men leaders themselves registered their candidacy in constituencies of Tarai, which were stronghold areas of these parties. Those women candidates not only lost the elections, they could not even secure their deposit (Election Commission, 1992, 2051 B.S. \& 2056 B.S.). Similarly, Nepal Workers and Peasants Party had fielded nearly 15 percent women candidates in HoR election 1994. It was a higher percent of women candidates in comparison of other parties in the election. But, the party won the election from Bhaktapur-1, Bhaktapur- 
2, Jumla-1, and Dailekh-2 (Election Commission, 2051 B.S., pp. 39-43), which were the stronghold constituencies of the party. All candidates of these constituencies were men. Women candidates of the party have fielded those constituencies where the situation of the party had poor. So, women could not win the election.

Only popular political parties secure their candidates. Independent women candidates could not perform strongly in the elections. Almost all the independent women candidates received less than 10 percent vote, therefore, they forfeited their election deposit. Even worse, most of the independent women candidates secured less than 1 percent vote of their constituencies.

\section{Electoral system and women candidates}

Among the electoral system, the majority system seems women candidates unfriendly. Many countries of the world, where majority electoral system adopted, fewer women could win the elections. Researchers concluded that PR systems are better at ensuring women's representation into parliaments as compared to plurality/majority systems (Dahlerup \& Freidenvall, 2005, p. 43; Matland, 2005, p. 93; Tripp and Kang, 2008, p. 343; Tremblay, 2008, p. 2; Kellow, 2010. p. 22). The practices of Nepal also witnessed the same fact. In HoR elections of 1991, 1994, and 1999 - where FPTP electoral system was used - not more than 12 women won the elections out of its 205 seats. In the CA elections 2008, 30 women candidates won the elections through the FPTP electoral system out of 240 seats. However, it was only 12.50 percent in comparison to men but it was the highest number of winner women in the history of elections of Nepal via majority electoral system. In the CA elections 2013, it dropped down to $10(4.17 \%)$ seats. Altogether, there were more than 30 percent woman members in both the CA; it was possible because of the PR electoral system, which was simultaneously used with FPTP electoral system.

\section{Inclusiveness of women candidates}

As figure-5 demonstrates, first, three elections of HoR were non-inclusive for women candidacy; whereas, CA election in 2008 and 2013, were more inclusive. There was no Dalit and Muslim woman candidate in HoR elections in 1991 and 1994. Similarly, there was no Tharu woman candidate in HoR election 1991. There were visible women candidates in CA 
elections in 2008 and 2013 from Dalit, Tharu, and Muslim communities. There were more Madhesi and Janjati women candidates in those elections, however, women candidates from Khas-Aarya was still dominated.

Figure 5: Women candidates regarding caste and ethnicity

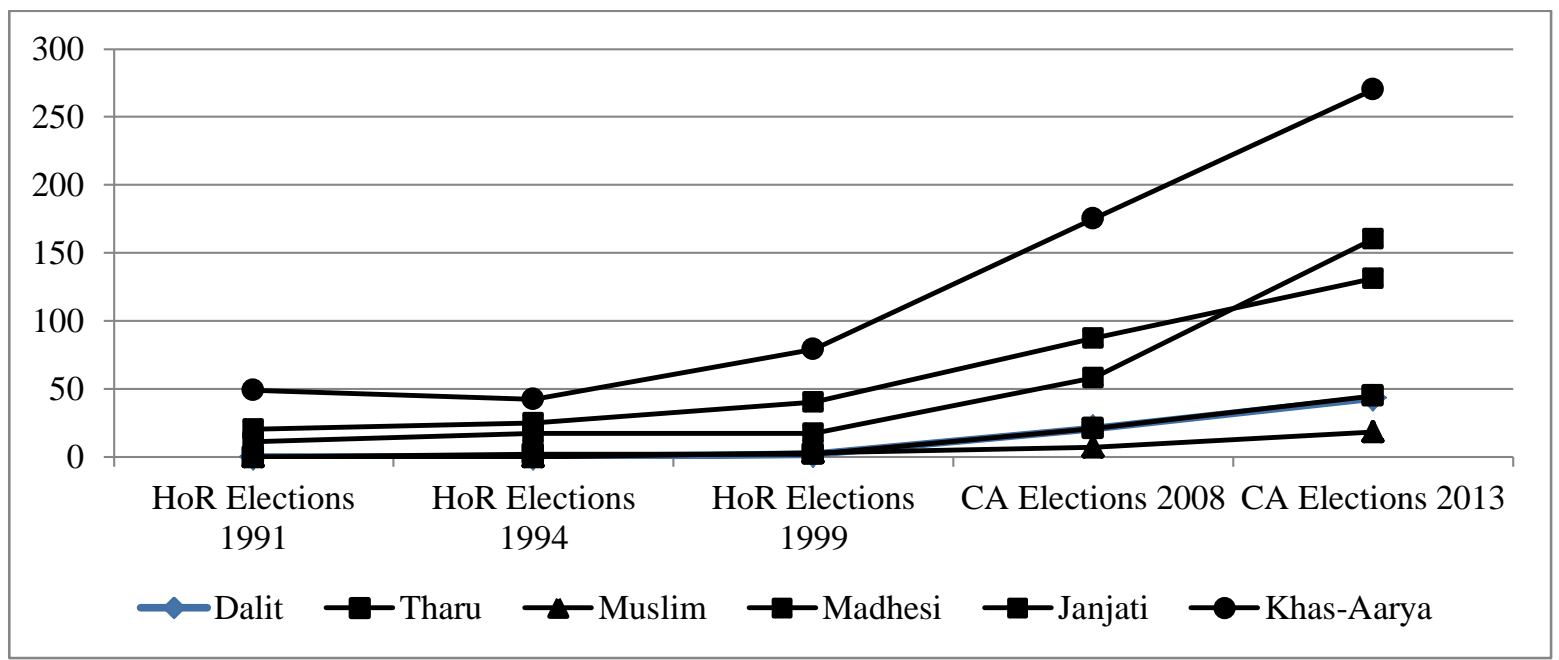

Source: Election Commission (1992, 2051 B.S., 2056 B.S., 2065 B.S. \& 2070 B.S.)

Candidates from most of the marginalized groups were not elected in those elections. Only two (out of seven) Janajati women won the elections in 1991 and 1994, and two (out of 12) Madheshi women elected in the elections of 1999; whereas, remaining all the elected women candidates of those elections were from Khas-Aarya community. Though, the result of the CA elections of 2008 and 2013 proved to be more inclusive.

The elections of the CA 2008 were women-friendly and historical. Out of 240 FPTP seats, 30 women candidates won the election. Women occupied 12.50 percent seats. However, it was only one-eighth of the total seats, so the achievement was not a significant one when seen through the lens of feminist perspective. Nonetheless, it was the highest number of winner women candidates through the FPTP electoral system in election history of Nepal. Twenty-four elected women were only from CPN (Maoist). Similarly, the CA was a mixed group of women that included Pratibha Rana of the royalist party RPP and her 
daughter Arzu Deuba of NC side by side with the CPN (UML)'s Shanta Chaudhari, a former bonded laborer (Kamaiya).

\section{Conclusion}

The trend of women candidates-reveals that they were mainly centered at the facilitated area. More women filed their candidacy in Kathmandu valley. Mountain region had fewer women candidates in comparison to Hills and Tarai. Similarly, the Far and Mid-western region had fewer women candidates than other regions of the nation. Because of less human development status and complex topography and underdevelopment status, women's candidacy was scanty in those regions. The major political parties have intended only to meet the constitutional provision of five percent representation of women candidates in a ritual manner. It was the main reason why the number of women candidates was very few in the previous five national elections of Nepal. It is also found that political parties nominated women candidates at those constituencies where chances to win the elections were very low. Similarly, it is also found that only the popular political parties like Nepali Congress, CPNUML, UCPN-Maoist and so on could assure victory for their women candidates. Independent women candidates could not perform strongly in the elections. PR electoral system favored more women to enter into the hall of power. First, three elections were non-inclusive nature as the women candidacy. The latter two elections, CA election in 2008 and 2013, were more inclusive. There were women candidates from Tharu, Muslim, Madhesi, and Dalit, too. Candidates from most of the marginalized groups were not elected in those elections.

\section{References}

Abcarian, G. (1982). On the political theories of radical and socialist feminism in the U.S.A. Politico, 47(2), 417-426. Retrieved from http://www.jstor.org/stable/43096839 Accessed: 17-03-2016.

Dahlerup, D. \& Freidenvall, L. (2005). Quotas as a 'fast track' to equal representation for women. International Feminist Journal of Politics, 7(1), 26-48, DOI:

$10.1080 / 1461674042000324673$ 
60

Election Commission (1992). General election in Nepal 1991, Kathmandu: Election Commission.

---. (2015). Election in Nepal: Nepal's Electoral History. Retrieved from www.election.gov.np, Accessed: 10-09-2015.

---. (2051 B.S.). House of Representatives members' election - 2051: election result description (in Nepali). Kathmandu: Election Commission.

---. (2056 B.S.). House of representatives members' election - 2056: Election result (in Nepali). Kathmandu: Election Commission.

---. (2065 B.S.). Constituent Assembly members' election 2064: Election result manual (in Nepali). Kathmandu: Election Commission.

---. (2070 B.S.). Constituent Assembly members' election 2070: Election result manual of first-past-the-post-election system (in Nepali). Kathmandu: Election Commission.

Fulton, S. A. (2012). Running backwards and in high heels: The gendered quality gap and incumbent electoral success. Political Research Quarterly, 65(2), 303-314. Retrieved from http://www.jstor.org/stable/41635235. Accessed: 07-12-2014.

Gaige, F., \& Scholz, J. (1991). The 1991 parliamentary elections in Nepal: political freedom and stability. Asian Survey, 31 (11), 1040-1060. Rertieved from http://www.jstor.org/stable/2645306. Accessed: 05/12/2014.

Gupta, A. (1964). Politics in Nepal. Bombay: Allied Publishers Pvt. Ltd.

Gurung, H. (1982). The Sociology of Elections in Nepal, 1959 to 1981. Asian Survey, Vol. 22, No. 3, 304-314. Retrieved from http://www.jstor.org/stable/2644032, Accessed: 05-11-2015.

Hachhethu, K. (2005). Political parties and elections. In L. R. Baral, Election and governance in Nepal (pp. 156-196). New Delhi: Mahohar Publishers. 
Herrnson, P. S., Lay, J. C., \& Stokes, A. K. (2003). Women running "as women": Candidate gender, campaign issues, and voter-targeting. The Journal of Politics, 65 (1), 244-255. Rertieved from http://www.jstor.org/stable/3449865. Accessed: 05/12/2014.

His Majesty's Government (HMG) (1990). Constitution of the Kingdom of Nepal. Kathmandu: Law Book Management Committee.

---. (2038/02/09). Nepal Rajpatra, Section 31, Additional Issue 4, Part 4. Kathmandu: His Majesty's Government.

---. (2043/02/18). Nepal Rajpatra, Section 36, Additional Issue 11, Part 4. Kathmandu: His Majesty's Government.

Institute for Integrated Development Studies (IIDS) (1993). The second parliamentary election: A study of the emerging democratic process in Nepal. Kathmandu: Institute for Integrated Development Studies.

Inter-Parliamentary Union (IPU) (2018). Women in parliament in 2017: The year in review. Geneva: Author. Retrieve from: https://ipu.org/resources/publications/reports/201803/women-in-parliament-in-2017-year-in-review

Kellow, T. (2010). Women, elections and violence in West Africa: Assessing women's paolitical participation in Liberia and Sierra Leone. London: International Alert.

Lama, S., Khakurel, D., Agrawal, K., \& Shrestha, M. (2011). Women members of the Constituent Assembly: A study on contribution of women in constitution making in Nepal. Kathmandu: Women's Caucus, Constituent Assembly Secretariat, Nepal Law Society and International Institute for Democracy and Electoral Assistance.

Lawless, J. L. \& Fox, R. L. (2010). It still takes a candidate: Why women don't run for office (Revised edition). New York: Cambrridge University Press.

Lengermann, P. M., \& Niebrugee, G. (2010). Contemporary feminist theory. In G. Ritzer, Sociological theory (pp. 454-498). New York: Mc Graw Hill. 
Leyenaar, M. (2008). Challenges to women's political representtion in Europe. Signs, 34 (1), 1-7. Rertieved from http://www.jstor.org/stable/10.1086/588435. Accessed: $07 / 12 / 2014$.

Malla, M. V. (2011). Political socialization of women in Nepal. New Delhi: Adroit Publishers.

Matland, R. E. (2005). Enhancing women's political participation: legislative recruitment and electoral systems. In J. Ballington, \& A. Karam, Women in parliament: Beyond numbers (pp. 93-111). Stockholm: International Institute for Democracy and Electoral Assistance.

Shvedova, N. (2005). Obstacles to women's participation in parliament. In J. Ballington, \& A. Karam, Women in parliament: Beyond numbers (pp. 33-90). Stockholm: International Institute for Democracy and Electoral Assistance.

Studlar, D. T. \& McAllister, I. (1991).Political recruitment to the Australian Legislature: Toward and explanation of women's electoral disadvantages. The Western Political Quarterly, 44(2), 467-485. Retrieved from http://www.jstor.org/stable/448790. Accessed: 05-12-2014.

Tremblay, M. (2008). Introduction. In M. Tremblay, Women and legislative representation (pp. 1-22). New York: Palgrave Macmillan.

Tripp, A. M. \& Kang, A. (2008). The global impact of quotas: On the fast track to increased female legislative representation. Comparative Political Studies, 41(3), 338-361. DOI: 10.1177/0010414006297342.

United Nations Development Programme (UNDP). Nepal human development report 2004: Empowerment and poverty reduction. Kathmandu: UNDP. 